\title{
The Role of the Russian Academy of Arts in the Revival and Development of Modern Religious Art
}

\author{
Shirshova Lubov \\ Russian State Specialized Arts Academy \\ Russian Academy of Arts \\ Moscow, Russia \\ e-mail: lshirshova@rah.ru
}

\begin{abstract}
The article explains the current at the turn of XX-XXI centuries multi-faceted educational activities of the Russian Academy of Arts for the preparation of highly artistic personnel capable to create works of Orthodox art. During this period the Academy consisted of two artistic high schools, two colleges and academic workshops of art.
\end{abstract}

Keywords-Russian Academy of Arts, Arts Education, the revival of the Russian Orthodox Church, temple art, religious artist.

\section{INTRODUCTION}

Fundamentals of modern art education are preserving and developing in the Russian Academy of Arts, which for nearly three centuries of its history has consistently offered one of the main centers of artistic life of the country. When in the early 1990s, it became apparent that the active work of the Russian Orthodox Church on the reconstruction and restoration of churches and monasteries requires a largescale training of highly professional artistic stuff, an important mission of training such professionals has been entrusted to the Russian Academy of Arts. Anti-church policy of the Soviet state in the twentieth century contributed to the fact that the traditions of Russian Orthodox art were largely lost. Accordingly, it was resulted in a number of consequences and, in the first place - lack of professional artists who can create works of Orthodox art.

It is known that the monumental church painting - is a special bi-unity of theological content and compositional and artistic structure. The revival of the church frescoes, forming of the integral method that combines the canon and nature, creating a picturesque ensemble, covering a large part of the church interior, turn out to be a difficult task in modern terms - at the turn of the twenty first century. Those who came into contact with the Orthodox painting frescoes, icons, - are well aware that this art requires extensive knowledge. Orthodox Church with its sophisticated harmony of architectural and pictorial forms, synthesis of sculpture and decorative arts, developed over the centuries. The creating of Orthodox painting demanded from the artist high professionalism, talent of muralist, compositional skill and spatial vision, imagination and deep knowledge of the Holy Scripture. At the end of the second half of the twentieth century academic classical school was faced with the need to revive the old system of education, where the use of native and international artistic experience was the basis of teaching methods of the future professionals - master-hands of church art. However, the main bases were not lost, as in all periods of the history of the country the system of academic art education defended those fundamental principles that were necessary in any historical circumstances and cataclysms. This, in particular, advertence to the artistic-wide training cycle, providing a high level of receiving professional education. You can completely agree with the statement that "school serves as a basis for the development of a new art, but art is becoming, in turn, the soil to form a new school. So this spiral is constructing infinitely in time, defining the evolution of painting, sculpture, graphic arts." [1]

\section{METHODS AND PRINCIPLES OF THE RUSSIAN ART EDUCATION IN THE XXTH CENTURY}

It was important that for the academic school educational principles of spiritual, philosophical and moral ideals had special meaning. The theoretical positions of pedagogical system of the Academy of Arts, developed by P. P. Chekalevsky are the evidence of that. He proclaimed the educational role as the main advantage of all the arts, because he believed that the art can provide "an invaluable service, using all the power of beauty to image the truth and virtue, two good things so necessary for humanity" [2].

In general, the basis of methods of teaching artists at the Academy of Arts for almost its entire history was a uniform system of education, "strict reasonableness, sequence of tasks and their progressive complexity combined artistic practice with scientific subjects" [3].

The teaching process (comprehension of the laws of drawing, sculpture, perspective, anatomy, composition, copy, etc.) was closely associated with the acquisition of practical skills; the getting of theoretical knowledge is also always combined with the practice.

By the second half of the twentieth century a school for the master-hands of monumental painting in two academic universities of art was formed: a training course lasted for six years. In pedagogical practice the experience of the past with its strict sequence in learning skills was used: in the early years of training there was a deep study of nature, many tasks in drawing, painting, sculpting, which 
complicated from semester to semester. The lectures on plastic anatomy, technique and technology of painting, composition, history of native and foreign art had been reading to the students. The summer practice was organized for the students of all faculties after each course

It should be emphasized that, along with the achievements of classical pedagogy the main centers of art education - academic institutes named after V. I. Surikov in Moscow and I. E. Repin in St. Petersburg - formed modern, well-developed program, the most accurate method to solve the problem of professional training of artists, architects, designers, restorers, art historians. The special subjects of art were built on consecutive study of monuments from different eras, including medieval. The part of the training of painters and restorers performed the practice of copy, including carrying out copies of icons, church frescoes.

A variety of tasks to be solved in copying of monuments of painting was extremely wide. Students, in particular, sought to understand and learn the value of the canons, the correct using of historical examples of iconography and techniques of the church frescoes. The trip to the summer practice (as before and now) was constant, students studied and copied church paintings, made measurements of cultural monuments. As a result, the extensive collections of copies of the church frescoes and mosaics were established in academic institutes named after V. I. Surikov in Moscow and I. E. Repin in St. Petersburg.

A careful study of the monuments of the past with the help of graphical analysis and a detailed study of the structure has contributed to a dual purpose: the enrichment of future masters with knowledge of styles, fashion, creative essays of the greatest artists of the past and at the same time - the development of their professional artistic skills on this basis.

At the beginning of the new millennium, with its radically different cultural and educational changes on the agenda once again become a problem of forming professionals who are able to respond the questions of the modern era. One of the main tasks of the pedagogical staff of two academic lyceums and institutes was the introduction of the practice of training and education oriented on person. Russian Academy of Arts, defending its traditions and system of values, identified ways to the further activity that can resist the aggression of mass culture. In the early 1990s, using extensive prior experience, formed in V. I. Surikov institute in Moscow and I. E. Repin institute in St. Petersburg, the Academy has begun work on the creation of infrastructure basis for the development of a national school of monumental art, the revival of Orthodox art school, the professional recovery of skill of church art as a fundamental principle of religious art.

\section{BYZANTINE TRADITIONS IN RUSSIAN ART}

It should be emphasized that in the academic courses of study a lot of attention was always paid to the aesthetic and ethical criteria of art, the basic principle of which is the statement of beauty and harmony - the most important components of religious painting. The ideological basis of national academic school was the works by outstanding native philosophers, historians, and theologians. In particular, its special significance received the ideas of the philosopher and theologian G. V. Frolovsky, who defended the importance of recognizing the Greek and Byzantine spiritual and historical tradition for Russia (in contrast to the Roman Catholic which formed the mentality of the Western world), and noted that the Byzantine Empire in 10th century was "the only true cultural country in the whole European world." In his conviction it was the Greek-Byzantine tradition that brought to the Russian Orthodoxy the great culture, the search for spiritual beauty, integrity and syncretism of the worldview. It should be noted that the baptism of Russia in 988 year according to the Byzantine Orthodox sample and the formation of the Russian national idea in Kiev's Rus, named as the "Holy Russia" were historically significant for Russia.

The assimilation of Greek-Byzantine and Russian spiritual and historical tradition by students of academic art institutes helped to understand why exactly Russia gave the world a pleiad of great ascetics of the Orthodox faith and masters of religious art.

\section{MODERN CHALLENGES AND TENDENCIES}

The development of the modern school of monumental painting also required the updating of training programs, development of new technologies and information systems, identified the need for qualitative growth of the teaching staff, capable of influencing the formation of the modern processes of art education. Occupying a leading position in native art education, academic institutions build the teaching methods in academic workshops of monumental art, closed to the traditional and at the same time - change the theme of the educational process according to increase the range of tasks specific to the modern period.

Thus, traditionally for the academic school (as before and in our time) one of the main subjects in the comprehension of professional skill of the painter still was the art of drawing; considerable importance is attached to the knowledge of anatomy, perspective, composition, technique and technology of materials. The modern system of art education, developing traditions, has opened access to the fundamentals of the art graphic tradition; the interest to the ancient art instilled in the second year. The development of artistic taste, deepening of professional skill appears during learning the Old Russian heritage.

A lot of attention is traditionally paid to the copy and restoration practice in the course of further education.

In the emerging professional environment the creation of master of church monumental painting is a syncretic relationship with other forms of art. The complex nature of teaching artists, working in related fields of art - are the basis of preparation of the masters of monumental painting, able to work in architecture (including in the church area) with large-scale themes. 


\section{THE MYLNIKOV's SCHOOL AND THE REVIVAL OF ORTHODOX PAINTING}

In this connection the continuity problem should be classified as an especially important issue, which can be viewed in this article through the example of pedagogical practice of an outstanding master of painting, academician of the Russian Academy of Arts, Professor A. A. Myl'nikov.

A. A. Myl'nikov - the oldest, an outstanding teacher of Repin St. Petersburg State Academic Institute of Painting, Sculpture and Architecture and nearly fifty years the head of the studio of monumental painting, he is truly considered to be the founder of a school of monumental art. In the 1960s, he is an innovator in the understanding of the aesthetic and artistic integrity of the new monumental art. The practice of temple murals becomes the new direction in the educational activity of his workshop (held in 1990). Today - it is an integral part of the learning process, which is being actively implemented after the third year of study. Its purpose is introduction to the art and technology of church art from different eras and mastering of the laws of monumental art in the real practice.

Synthetic character of professional training, practical learning of the types of work in the related fields of art and architecture - all this is taken into account as much as possible in the learning process today and it provides the "entering" the future masters of monumental art to the specifics of the various art forms, forms the knowledge according to the practical solution of synthetic problems.

At the turn of XX-XXI centuries the graduates of A. A. Myl'nikov workshop (it is a number of generations, constantly with high creative professionalism) gather together in creative teams to carry out the monumental church works. The muralists S. N. Repin, V. V. Sukhov, N. P. Fomin, A. A. Pogosyan, A. V. Belov, O. A. Denisenko, A.Y. Sinitsa, A. V. Charin, A. V. Chuvin, A. L. Ivanov recreate the painting of the Cathedral of Christ the Savior in Moscow, they work in the churches of St. Petersburg and other Russian cities, as well as in churches around the world.

The mosaic workshop of the Russian Academy of Arts in St. Petersburg, founded in 1851 for making the mosaics of St. Isaac's Cathedral, nowadays actively developed under the leadership of one of the best students of A. A. Myl'nikov - A. K. Bystrov - Academician of the Russian Academy of Arts, Professor. In the Soviet period there were created mosaics for the decoration of public buildings and subway stations. At the turn of XX-XXI centuries the tradition of making mosaics was continued in churches in Russia and abroad. The workshop is now involved a group of artists participating in recreating the paintings of the Cathedral of Christ the Savior in Moscow: A. Belov, Y. Behova, A. Denderina, A. Zhivaev, L. Kokov, E. Panikarova, brothers A. and A. Parshin, V. Perkhun, S. Pichakhchi, T. Chikova, S. Shterenberg, O. Schulz, P. Yakymchuk.

A workshop of painting restoration organized in 1970, now led by Academician, Doctor of Arts, Professor J. G. Bobrov, works in the institute successfully. No exaggeration to say that this workshop is the best in terms of training art restorers in our country. In the $1990 \mathrm{~s}$, educators of the workshop facilitated the establishment of the Department of restoration of icons (opened in 1993) at the Faculty of Church Arts in the St. Tikhon's Orthodox University in Moscow.

The prerequisites for the development of Orthodox painting, made in an academic manner, were closely associated with the system of professional training of artists, where the foundation has always been educational ideology of the academic school. However, church art requires from the master special knowledge, spiritual training and theological education. Needs of church practice in the resumption of "church beauty in the temples" dictated the creation of academic institutions in special workshops. The president of the Russian Academy of Arts Z. K. Tsereteli, knowing about the prospect of rebuilding the Cathedral of Christ the Savior in Moscow, supported the initiative of academician of painting, Professor A. A. Myl'nikov about the restoration of historical and religious paintings workshop in 1993 in St. Petersburg Academic Institute of Painting, Sculpture and Architecture named after I. E. Repin. The artists who can work professionally in the bosom of the Orthodox Church are trained here under the guidance of Professor A. K. Krylov, a student of A. A. Myl'nikov.

The course of study in this workshop, along with subjects which provides training program of painters, has a number of features: for example, a harmonious combination of moral education and training, orientation on canonical Byzantine and Old Russian art, more serious theological training, spiritual and personal involvement of future iconographer in creating the image [4] .

The possibility of obtaining special education in the workshop of historical and religious paintings made the independent profession of church painter in the national fine art workable. This affected the general settings of the educational process, in which individual tasks received their special touch. As emphasized above, the role of the medieval tradition at the turn of XX-XXI centuries became great as in style and in the theoretical explaining of the creative process and in the revival of art education methodology of church painting masters. The presidium of the Russian Academy of Arts and its president Z. K. Tsereteli, bearing in mind all these factors, identify new challenges of improvement of the faculty of painting in academic art institutes. The practice of students' participation (under the guidance of teachers) in the creating of church murals is actualized much today. So, the restoration and reconstruction of the decoration of the academic home church of St. Catherine, arranged in the Academy of Arts in St. Petersburg were made mainly by the students and graduates of academic institute named after I. E. Repin.

In 1991 in an academic home church the service was continued after nearly sixty years of hiatus. The prior of the church, father Alexander (Fedorov) - is a graduate of I. E. Repin Institute. The revival of academic church - it is really the embodiment of the living connection between 
generations; in this regard should be specially emphasized that today continues the knowledge of the basics of spiritual life through prayer in the home church of St. Catherine. [5]

\section{CONTEMPORARY AGENDA OF HigHER ART EDUCATION IN RUSSIA}

The next part of the whole system of higher art education should be regarded as solving problems of synthesis of arts in teaching future muralists. The researcher E. N. Nikolaeva learning the art of students of the Faculty of Painting in I. E. Repin Institute in the 1990s, analyzed the process of formation of religious subjects at the turn of XXXXI century. [6] In the practice of the masters of monumental church painting, as the researcher notes, the importance has the solving of problems of synthesis of arts, the ability to combine organically paintings with architectural composition.

Long-term urban planning and artistic practice of graduates of academic institutes became a convincing evidence of this statement.

A real school of academic excellence was the participation of fifth-year students of monumental painting workshops of Repin academic institute in St. Petersburg and Surikov institute in Moscow in recreating the beautiful decoration of the Cathedral of Christ the Savior in Moscow.

There is a workshop of monumental painting under the guidance of Academician of the Russian Academy of Arts, People's Artist of Russia, Professor E. N. Maximov in V. I. Surikov Moscow State Academic Institute; it was established in 1939 by an outstanding master of painting, Academician, People's Artist of the USSR A. A. Deineka. The educators of the workshop S. A. Gavrilyachenko, A. D. Kornaukhov, I. L. Lubennikov, V. P. Myasoedov, V. N. Slatinsky methodically restore a single connection between modernity and deep traditions of Russian culture, seeking to eliminate the historically artificial hiatus. Considerable attention is paid to the study of religious art, historical and religious paintings.

In this connection, it should be emphasized the role of E. N. Maximov, influenced the development of the church monumental painting in our country: in the past twenty years he became a founder of an entire school of monumental Orthodox painting, realizing his creative individuality in the educational process, training many talented graduates of the workshop of monumental painting in V. I. Surikov institute.

An academician E. N. Maksimov at the end of the 1990s was the organizer of the Faculty of Fine Arts in Saint Tikhon's Orthodox University in Moscow. The graduates of V. I. Surikov Moscow State Academic Art Institute specializing in the workshop of Professor E. N. Maksimov: I. Y. Samolygo, N. I. Samolygo, L. G. Gacheva, M. O. Glebova and others are the main part of the teaching staff of the Faculty of Fine Arts.

The graduates of V. I. Surikov Moscow State Academic Art Institute specializing in the workshop of Professor E. N.
Maksimov work as a teacher in the Theological Institute of St. John the Russian Orthodox Church in Moscow.

Much theoretical and practical training of graduates of academic institutes in Moscow and St. Petersburg contribute to the development of religious art in our country and abroad.

\section{CONCLUSION}

Thus, we can say that the education received in art lyceums, universities and art workshops included at the turn of XX-XXI centuries in the structure of the Russian Academy of Arts, "is seen as a creative act (humanized, humanitarian approach), the pursuit of interdisciplinary synthesis of science, education and culture, the integral person (on the psychological, social and cultural levels)"[7].

Many things are changing: attitudes, spiritual life, needs of society and at the same time education, through which the society develops with its economic, political and social strategies. Education is at the core of the cultural life of the community with its enduring values and traditions. Education is the cultural core of social life with its enduring values and traditions. Importance of the Russian Academy of Arts - the leading center of artistic education in the country - is determined primarily by the fact that the development of modern orthodox painting took place under conditions of intensive formation of a national art school. Many years of artistic experience and tradition of the educational system, developed at the Russian Academy of Arts, contributed to the revival and development of the national school of church art.

\section{REFERENCES}

[1] N.M. Moleva, E.M. Belyutin, "The Russian Artistic School in the later half of the 19th century and in the early 20th century". - M.: Iskusstvo, 1967. - P. 313.

[2] P.P. Chekalevsky, "The Essay on Free Arts". - SPb., 1872. - P. 34.

[3] V.T. Bogdan, "Hystoric Class of the Art Academy in the later half of the 19th. - SPb.: NP-Print, 2007. - P.9.

[4] A.K. Krylov, Fifteen Years of the Devotional-Historical Art Workshop. Results and Perspectives// The Makariy readings. Materials of the 25th Russian Scientific Conference, dedicated to the Holy Hierarch Marakiy. - Mozhaysk: Terra, 2008. - PP. 128-140.

[5] The Saint Catherine Chapel of the the Art Academy in St.Petersburg. - SPb.: Znaki, 2005. - 94 P.: il.

[6] E.N. Nikolaeva, Religious Themes in the Works by Art School Students. 1990s. The Workshop of Easel and Monumental Painting. SPb., 2003. - P 47.: il.

[7] N.I. Voronina, Cultural Policy Kulturnaya in the Space of Modern Provinces. // Reporter of the Mordovian University. The series of Humanitarian Social and Economic Sciences. - Saransk, 2014. - No.4. - P. 193 